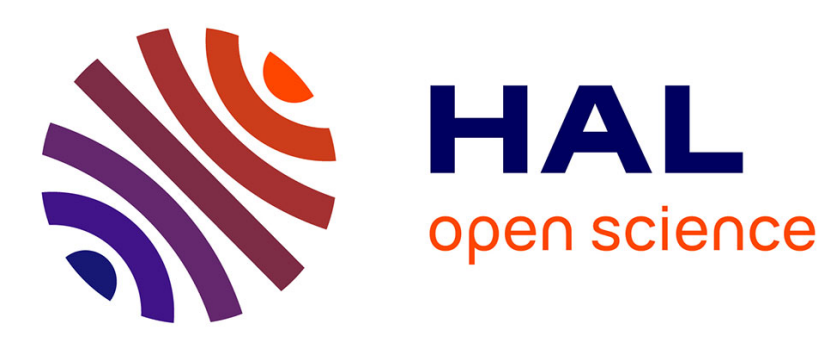

\title{
Molecular effects of oestrogen inhibition in breast cancer
}

William R. Miller, Alexey Larionov

\section{To cite this version:}

William R. Miller, Alexey Larionov. Molecular effects of oestrogen inhibition in breast cancer. Molecular and Cellular Endocrinology, 2011, 340 (2), pp.127. 10.1016/j.mce.2011.04.020 . hal-00717912

\section{HAL Id: hal-00717912 \\ https://hal.science/hal-00717912}

Submitted on 14 Jul 2012

HAL is a multi-disciplinary open access archive for the deposit and dissemination of scientific research documents, whether they are published or not. The documents may come from teaching and research institutions in France or abroad, or from public or private research centers.
L'archive ouverte pluridisciplinaire HAL, est destinée au dépôt et à la diffusion de documents scientifiques de niveau recherche, publiés ou non, émanant des établissements d'enseignement et de recherche français ou étrangers, des laboratoires publics ou privés. 


\section{Accepted Manuscript}

Title: Molecular effects of oestrogen inhibition in breast cancer

Authors: William R. Miller, Alexey Larionov

PII:

DOI:

S0303-7207(11)00229-2

Reference: doi:10.1016/j.mce.2011.04.020

To appear in: $\quad$ Molecular and Cellular Endocrinology

Received date: $\quad 21-7-2010$

Revised date: 26-4-2011

Accepted date: $\quad$ 26-4-2011

Please cite this article as: Miller, W.R., Larionov, A., Molecular effects of oestrogen inhibition in breast cancer, Molecular and Cellular Endocrinology (2010), doi:10.1016/j.mce.2011.04.020

This is a PDF file of an unedited manuscript that has been accepted for publication. As a service to our customers we are providing this early version of the manuscript. The manuscript will undergo copyediting, typesetting, and review of the resulting proof before it is published in its final form. Please note that during the production process errors may be discovered which could affect the content, and all legal disclaimers that apply to the journal pertain. 


\section{Molecular effects of oestrogen inhibition in breast cancer}

William R Miller ${ }^{1,2}$ Alexey Larionov ${ }^{3}$

${ }^{1}$ Breast Research Group, University of Edinburgh, Western General Hospital, Edinburgh, United Kingdom;

${ }^{2}$ Present address: 2 Stoneycroft Road, South Queensferry, EH30 9HX, West Lothian, UK

${ }^{3}$ Edinburgh Breakthrough Breast Research Unit, Edinburgh University, Western General Hospital, Crewe South Road, Edinburgh, EH4 2XU 


\section{ABSTRACT}

This paper reviews the effects of oestrogen deprivation by third generation aromatase inhibitors on molecular profiles in breast cancers. It particularly focuses on results obtained as a result of pre-operative and neoadjuvant therapy in which primary breast cancers have been biopsied or excised before and during treatment with letrozole, anastrozole or exemestane. Studies may be subdivided into those evaluating early (10-14 days) or late (3-4 months) changes; a single investigation charted sequential changes. Early changes involved downregulation of genes classically induced by oestrogen or associated with cell cycle and proliferation. In contrast, expressions of genes associated with stromal signatures were upregulated. Considerably more genes were changed at later time-points; these probably represent not only primary effects on cellular expression but the secondary consequences on cell death and clonal selection. Thus, after 3-4 months of treatment mitochondrial-related genes and those associated with cell cycle and cell division were downregulated whereas genes associated with extracellular matrix (ECM) remodeling, vascularization, inflammatory responses and cell adhesion were upregulated. Recently, observations have been reported from a study in which tumours were sequentially sampled to include pretreatment and both early and later time-points. This allowed direct monitoring of the dynamic changes in gene expression. Different patterns of changes in gene expression were identified which were also associated with general differences in sub-cellular distribution of functional proteins. The effect of treatment on expression of specific genes and processes such as aromatase, oestrogen receptor (ER), oestrogen-regulated genes, HER2, p53, ribosomal proteins, markers of proliferation, oxidative phosphorylation and stromal response are summarized. 


\section{INTRODUCTION}

Oestrogens have a major role in the regulation and function of many developmental processes in multiple target organs. Additionally abnormal, excessive or prolonged stimulation by oestrogen can result in malfunction and be associated with disease. There has therefore been great interest in understanding the mechanism of action of oestrogen and the consequences of oestrogen deprivation. In terms of deprivation, trophic effects of oestrogen may be reduced by inhibiting biosynthesis or by blockade of hormone action [1,2]. In recent times the

pharmaceutical industry has been extremely successful in developing agents such as aromatase inhibitors and anti-oestrogens [3-5] which efficiently and specifically affect these processes. Such drugs have advanced scientific knowledge and clinical practice in a variety of settings. However, this particular review will focus upon the effects of third generation aromatase inhibitors as used to treat postmenopausal patients with breast cancer.

After the menopause, sites of oestrogen biosynthesis (possessing aromatase activity) in breast cancer patients are primarily peripheral tissues such as adipose tissue, muscle and tumour (sites which are not amenable to ablation) - hence, the need for agents which inhibit aromatase effectively and specifically in peripheral tissues. Most experimental models for breast cancer in postmenopausal women are highly artificial and can be lacking in relevance. Thus the most compelling evidence for proof of principle and mechanism action has been derived from patients themselves. Additionally, the reversible nature of some inhibitors [6] necessitate that studies are performed in the presence of the drug and preferably in situ within patients. Because of this, the present paper will only review (i) studies in which aromatase inhibitors have been given to breast cancer patients in the immediate pre-operative period before tumour is excised or (ii) neoadjuvant protocols in which agents are given before surgery with the intent of reducing tumour size. Effects of oestrogen inhibition are measured on primary breast cancers exposed to the appropriate pharmacological doses of the drug in the post-menopausal setting.

Because of the special nature of this volume, it is important to recognise the contribution of Professor Mike Reed to this field of study and most particularly to our own research. Thus, Mike was amongst the first to show that breast cancers had both the ability to concentrate oestrogen from the circulation and to synthesise oestrogen locally [7]; this by developing and optimising a dual isotope perfusion technique which could be applied to patients with breast cancer. One of the major objectives of our research was to compare the efficacies of aromatase inhibitors on intratumoural aromatase. Ex vivo studies measuring aromatase activity in tumours taken from patients before and after treatment with aromatase inhibitors had yielded paradoxical results [8]. The need for in situ measurement of aromatase activity was obvious. Mike had accomplished this by employing perfusion methodology [9]. His help allowed us successfully to compare the effects of third generation inhibitors on both peripheral and intratumoural oestrogen biosynthesis in patients given neoadjuvant treatment with aromatase inhibitors $[10,11]$. These studies were the forerunners of those determining effects on molecular profiles which are the subject of the present review. 


\section{RESULTS}

\section{Early Effects}

Two informative studies have looked at molecular response to aromatase inhibitors after 10-14 days of treatment $[12,13]$. Miller et al studied sequential biopsies taken during neoadjuvant treatment with letrozole: core biopsies were taken before and after 2 weeks of treatment [12]; Mackay and co-authors studied sequential biopsies taken before and after a short period of preoperative treatment (either with anastrozole or letrozole) immediately before surgery [13]. The molecular responses observed in both studies were generally consistent. Aromatase inhibitors suppressed expression of classical oestrogen-dependent and proliferation-related genes, such as TFF1, KIAA0101, PDZK1, AGR2, ZWINT, IRS1, CDC2, CCND1, CCNB1, NUSAP1 and CKS2. The most consistently upregulated genes were enriched for those associated with 'stromal signatures' which included specific types of collagens (COL3A1, COL14A1 and COL1A2), members of a small leucine-rich proteoglycan family ( $D C N, L U M$ and $A S P N)$, genes associated with cell adhesion and intercellular matrix turnover (MMP2, CD36, CDH11, ITGB2, $S R P X, S P O N 1$ and DPT) and immune response-associated genes (COLEC12, IL1R1, C1R and TNFSF10).

The ontology of downregulated genes was functionally associated with cell cycle progression, particularly mitosis. In contrast, upregulated genes were associated with organ development, connective tissue extracellular matrix regulation (collagens), inflammatory response and lipid storage. It should be emphasized that these molecular changes (being observed as early as after 2 weeks of treatment) were much in advance of evident morphological changes.

Mackay et al [13] studied effects of both letrozole and anastrozole but detected no significant differences between the inhibitors. The group went on to relate molecular changes to proliferative response as assessed by Ki67 immunostaining. The total number of genes significantly changing on treatment (Global Index of Dependence on Estrogen [GIDE]) varied markedly between tumours but was related to changes in Ki67.

In the neoadjuvant study reported by Miller et al, it was possible to assess clinical response after 3 months of treatment and search for early changes in gene expression profiles that could predict for clinical response to neoadjuvant letrozole [14]. In responsive tumours there was a higher expression of ribosomal proteins before treatment compared with levels in resistant tumours. Following 2 weeks of letrozole, expression of ribosomal proteins was decreased in the responsive group. In contrast, the baseline expression of ribosomal proteins in resistant tumours was low and increased by treatment. Changes in proliferative and classic oestrogen responsive genes did not have strong correlation with clinical response, occurring in both clinical responders and non-responders (although more frequent in clinically responding tumours) [14,15]. 
Late Effects

The effects of more prolonged treatment have usually been assessed at 3-4 months, this being the typical length of therapy given in the neoadjuvant setting. Influences of more extended treatment have not been published. After 3-4 months of treatment, marked changes in clinical size and histopathology may be seen in some (but not all) breast cancers [16,17]. It is likely therefore that late molecular changes may be mediated not only by intracellular effects but by secondary influences, most notably changes in cell numbers and populations. Such heterogeneity and clonal selection complicate interpretation of results, especially when small numbers of tumours are included in studies. In this respect it should be noted that Miller et al [12] recruited 54 patients treated with letrozole, Mello Grande et al [18] reported on 13 paired samples before and after anastrozole, and Harvell et al [19] 4 patients treated with exemestane.

The following general conclusions may be derived from the published literature. Firstly, there are many more genes with expression changes at 3-4 months than at 10-14 days, although many of the genes affected at 14 days are also altered at 3-4 months (see section on sequential changes). In terms of functionality, genes changed at 3 months were associated with inflammatory responses, ECM and cell adhesion (upregulated), cell cycle and cell metabolic processes terms (downregulated).

Some studies have also attempted to show differential changes in subgroups identified according to clinical response. Thus Mello Grande et al [18] suggested there was an enrichment of induction of T-cell anergy, positive regulation of androgen signaling, synaptic transmission and vesicle trafficking in non-responders to anastrozole, and of cell cycle inhibition and induction of immune response in responders. Harvell et al [19] suggested upregulation of a 'lipogenic' pathway was a marker of intrinsic resistance although this was based on only a single exemestane non-responsive cancer.

It should be noted that these late differences between responding and non-responding tumours are interesting but they may have little relevance to prediction of clinical response because by 34 months the response is already manifest. Indeed, differences may be a result of response or even be the source of evidence for early resistance. In terms of resistance, Creighton et al [20] reported that both CD44+/CD24-/low-mammosphere forming and claudin-low signatures were more pronounced in tumour tissue remaining after 3 months letrozole treatment. This would be consistent with the selective survival of tumour-initiating cells. These data provide supporting evidence that the residual breast tumour cell populations surviving after treatment may be enriched for subpopulations of cells with both tumour-initiating and mesenchymal features.

\section{Sequential Effects}

While there is a limited number of studies reporting changes between two biopsies from the same tumour $[12,13,18,19]$, to the authors' knowledge, only 1 investigation has monitored 
dynamic changes by measuring expression profiles in 3 sequential biopsies from individual breast cancers. [21]. Microarray analysis was performed on RNA extracted from sequential tumour biopsies taken before, after 14 days and after 3 months of treatment with letrozole in 54 patients. The study confirmed that the numbers of genes changed at 3 months was substantially higher than those at 14 days (1503 and 237 genes respectively). The proportion of transiently regulated genes (changed at 14 days only) was small, $85 \%$ of the changes identified at day 14 being also observed at 3 months. Gene ontology (GO) analysis showed that early stably changed genes were associated with cell cycle (downregulation), blood vessel development and extracellular matrix (upregulation). GO terms describing the late changes (observed at 3 months only) included "cellular metabolic process", "generation of precursor metabolites and energy" (decreased); and "cell adhesion" and "biological adhesion" (increased). A comparison of GO terms for biological functions for both down- and up-regulated genes at 14 days and 3 months is shown in Table 1. The corresponding GO terms for cellular location are summarized in Table 2. A striking difference between the early and late changes was the cellular location of GO terms for downregulated genes: at 14 days, the GO terms were generally associated with nuclear structures but, after 3 months, the major changes were detected in mitochondria, specifically in the inner membrane. This can be illustrated graphically by comparing GO terms relating to 'chromosome' and 'mitochondria' (Figure1). Interestingly, the GO terms for upregulated genes were essentially the same at 14 days and 3 months, being associated with extracellular matrix.

Gene Patterns according to Chronology of Change

Knowledge of the sequential changes of expression in individual genes with time of treatment can be utilised to group genes according to whether the changes are rapid, gradual or late as illustrated in Figure 2a. Illustrative examples of individual genes representing each of the classes are shown in Figure 2b (CD 36 - rapid upregulation, PTN gradual upregulation, JUN late upregulation, MAPT - rapid downregulation, NAT1- gradual downregulation and HBB delayed downregulation). The full list of genes for each pattern is given in the supplementary file.

\section{Specific Genes}

It is of interest to examine the effects of oestrogen deprivation as produced by treatment with an aromatase inhibitor on specific genes/groups of genes potentially involved in breast cancer response/resistance to treatment. The following section seeks to achieve this objective by interrogating the database provided by the study of Miller et al 2010 [21].

Aromatase: None of the microarrays from pre-treatment biopsies were called 'present'; on treatment samples were labelled 'present' in only 3 cases. This represents very low expression from which no definitive conclusions about dynamic of changes can be derived. 
Oestrogen Receptors (ER): Figure 3a shows the average change in ER (probe 205225_at) at 14 days and 3 months. There appears to be tendency for the expression of ER mRNA to decrease progressively with time of treatment. However, the heatmap illustrating changes in individual cases indicates that marked changes occur in only occasional tumours at 2 weeks of treatment but these are more frequent (but often in different cancers) at 3 months.

Oestrogen regulated genes: KIA0101, TFF1, TFF3, IRS1 and SERPINA3 are genes whose expression is stimulated in a variety of oestrogen-sensitive systems [22-25]. The average change in expression produced by letrozole in breast cancers is summarized in Figure 3c. There was a rapid and sustained decrease in mRNA expression of all these genes. The corresponding heatmap illustrating individual cases shows that the reduction occurred in the majority but the corresponding evidence was not evident in occasional cases.

HER2: Positive calls for HER2mRNA expression was observed in about a half of tumours. In these cases, the effect of treatment was generally marginal; in the few tumours with more marked changes, decreases were as frequent as increases.

P53: The expression of p53 (probe 201746_at) was called positive in $>85 \%$ of cases. There was a tendency for a decrease in RNA with treatment at 14 days which became more pronounced at 3 months (Figure 3b).

Ribosomal proteins: Because of the previous observations [14,26] that change in expression of ribosomal proteins may be different in breast cancers which respond clinically to letrozole and those that do not, it was of interest to investigate their dynamics of change following letrozole treatment. These results are shown in Figure 4a for letrozole responsive and resistant subgroups of tumours and the whole series. The figure shows data for 7 different ribosomal proteins selected on the basis that they change differentially after 14 days of letrozole treatment in responsive and resistant tumours. It can be seen that the average change in the tumour series as a whole is relatively small but when the group is subdivided into responders and nonresponders, there is a clear increase in expression at 14 days in resistant tumours in contrast to a decrease in responders. Interestingly, the differential effect is much reduced at 3 months. The changes in individual tumours are shown in the heatmaps (Figure $4 \mathrm{~b}$ ).

\section{Specific Processes}

In breast cancers oestrogen is thought to regulate important processes such as proliferation, metabolism, stromal/epithelial interactions and intracellular signalling. It was therefore of interest to examine the effects of oestrogen deprivation on these processes.

Proliferation: The effects of letrozole treatment on the expression of several classical markers of proliferation (CDC2, CCNB1, CKS2, THMK, PCNA) [27-30] are summarised in Figure 3d. The average expression of all genes was decreased at 14 days and was maintained low at 3 months. However, as can be seen from the heatmap, the effects were not uniform and either the decrease 
was not seen or expression was increased in occasional tumours. These observations would be consistent with the protein expression of the proliferation marker, Ki67 in breast cancer including the cases illustrated in Figure 3 [32].

Stromal response: One of the most consistently and significantly upregulated group of biological processes following oestrogen deprivation in breast cancers is 'stromal response'. This term embraces a variety of closely related processes including extracellular matrix remodelling, invasion, angiogenesis, cell adhesion, inflammation and immune response. Changes in selected genes reflective of these processes are depicted in Figure 5a. Increase in expression was noted in all genes. Whilst effects were generally more pronounced at 3 months, this was not always the case; for example genes associated with blood vessel development increased rapidly and there were only small differences between average changes at 14 days and 3 months (Figure $1 b$ ).

Oxidative phosphorylation: many genes changed by letrozole treatment (see section on late changes) are mitochondrial-related. Indeed, they represent about 5-10\% of nuclear DNAlocated genes associated with mitochondria. These include genes linked to oxidative phosphorylation. Representative genes for subunits of ATP synthase, cytochrome-c oxidase and NADH dehydrogenase are shown in Figure 5b. All genes show a marked decrease in average expression but only at 3 months.

\section{DISCUSSION}

The present review considers the molecular effects of oestrogen deprivation as produced by treatment with highly specific third generation aromatase inhibitors on breast cancers in postmenopausal women. This represents a comparatively restrictive study group and results are drawn from a relatively small number of published studies. Data from experimental animals and cell lines are not considered because most are not relevant clinical models for postmenopausal breast cancer patients. Despite the small number of studies directly reporting changes in clinical breast cancer specimens, it is clear that several important conclusions may be derived. Thus, i) there is a general consensus about the most consistent mRNA expression changes in breast tumours occurring as a result of oestrogen deprivation, ii) the molecular changes are dependent upon the time of oestrogen deprivation and iii) there is heterogeneity of effects between different breast cancers. Each of these points is worthy of further discussion.

In terms of generic results from published studies $[12,13,18]$ there is general agreement about the type of genes affected by aromatase inhibitors. Thus, amongst the genes most significantly downregulated are KIAA0101, ZWINT, PDZK1, UBE2C, IRS1 and trefoil factors 1 and 3. These are classical examples of oestrogen-regulated genes whose expression has been shown either to be induced by oestrogen or reduced by antioestrogen treatments in experimental systems [2225,31]. Significantly downregulated probes also included those for genes associated with promoting proliferation, for example CDC2, thymidylate synthetase, cyclin B1, PCNA and CKS2. These genes have already been shown to be downregulated by oestrogen deprivation in 
other oestrogen-responsive systems $[23,27,30]$. Their identification is consistent with the antiproliferative effects (reduction in immunohistochemical staining for Ki67) seen in many of the same tumours [17,32]. Gene ontology analysis confirmed that downregulated genes were significantly enriched by those functionally associated with proliferation, cell division and cell cycle progression, particularly mitosis.

In contrast, upregulated genes are associated with organ development, connective tissue extracellular matrix regulation and inflammatory response. Analysis of individual genes involved in stromal response shows that many of them may be involved in multiple processes simultaneously, such as adhesion, angiogenesis, stromal remodelling and invasion [33]. Amongst the most consistent findings is upregulation of different types of collagen. In this respect, it should be noted that most protocols have not attempted to enrich tumours for their malignant component and therefore genetic changes may occur in multiple tumour compartments. Alterations in the expression of certain genes may therefore not occur primarily in the malignant component but, for example, in stroma [34].

In view of consistent data about transcriptional changes associated with proliferation and stromal response, it may seem odd that genome-wide transcriptional studies on endocrine treated clinical breast cancers have not reported similar major consistent findings for any major signal transduction pathway. Although mRNA expression of isolated signalling molecules may change significantly after treatment (eg Jun in Figure 2) the biological meaning of these findings is not immediately clear because activity of signalling greatly depends on presence of ligands and posttranslational events (eg phosphorylation/de-phosphorylation) rather than on the transcriptional changes of the signalling molecules only.

Another major conclusion that can be drawn is that the nature and size of the molecular effects detected in breast cancers following treatment with aromatase inhibitors is heavily dependent upon time of exposure to the agents. This can be concluded indirectly by comparing the results of separate studies examining either days or months of treatment or more directly from the single study in which sequential triple biopsies were taken from the same tumours before and after 14 days and 3 months of treatment. A major observation is that the number of changed genes was substantially higher after 3 months $(1,000 \mathrm{~s})$ than after 14 days of treatment (100s). As most of the genes changed at 14 days were also identified at 3 months, the extra genes at the later time-point may represent secondary events occurring in response to primary molecular changes. This would be compatible with changes in tumour morphology and pathology (most notably decreases in cellularity and increases in fibrosis) which were rarely seen at 14 days but relatively frequent after 3 months in breast cancers following treatment with aromatase inhibitors [17]. Hence, late genetic changes are likely to reflect not only phenotypic intracellular events but also effects on cellular populations.

There are interesting similarities and differences between changes evident at 14 days and 3 months. In terms of similarities, many genes changed at both 14 days and 3 months code for cell cycle proteins, regulators or are markers of proliferation; GO terms for downregulated 
genes include "cell cycle" and "M phase" at both time-points. These observations are again consistent with the protein expression of markers such as Ki67 which are markedly decreased by letrozole at both 14 days and 3 months [32]. However there were also marked differences in gene expression changes at day 14 and 3 months as reflected in their GO terms. Thus, "cellular metabolic process" and "generation of precursor metabolites and energy"'" were the most significantly-enriched downregulated terms at 3 months, but are not amongst the top enriched terms at day 14. There is also a major change in the cellular localization of the downregulated genes - nuclear and chromosomal distribution being apparent at 14 days whereas mitochondrial association (inner mitochondrial membrane) predominate at 3 months. These results clearly indicate that the nature of genes changed by oestrogen deprivation following aromatase inhibitor treatment will be heavily influenced by time of exposure to the agents.

When gene expression profiles are studied at multiple consecutive time-points in the same tumours, it was possible to examine the dynamics of gene expression and categorize genes according to patterns of change. It has thus been possible to subdivide genes into major groups. The largest grouping comprised genes whose expression changed steadily and gradually over 3 months. Other major groups include genes which displayed rapid (as early as at 2 weeks) sustained changes and genes whose expression changed only after prolonged treatment.

The above considerations are based on general average changes within groups of breast cancer but it is equally clear that there is a marked diversity or heterogeneity between individual tumours. Thus individual tumours may fail to exhibit common molecular responses or even demonstrate the opposite. For instance, we have identified a small subgroup of tumours that displayed paradoxical downregulation in a diverse set of genes which were consistently upregulated in the remainder of the series [12]. These observations emphasise the differences between individuals and groups of tumours. Most notably, there is a wide heterogeneity in clinical, pathological and proliferative responses to oestrogen deprivation and other forms of endocrine therapy $[16,17,32,35]$. It is therefore vital to relate differences in molecular responses to these other endpoints to determine whether they may be markers of such responses or even the mediators of the response or the mechanism of resistance. For example, the divergent changes in ribosomal proteins which occur in clinically responsive and resistant tumours needs to be explored further. In terms of prediction, early changes occurring before evidence of clinical response are most relevant and late changes may by the result rather than the cause of clinical, pathological or proliferative responses. Finally, given the diversity of molecular responses which vary with time and the inherent heterogeneity between breast cancers, it is imperative that sufficient numbers are entered into research protocols and caution should be urged when deriving conclusions on small numbers of tumours.

\section{CONCLUSION}

Oestrogens have profound effects on breast development and cancer. Agents targeting oestrogen signalling and synthesis, most notably third generation aromatase inhibitors, have established a role in the prevention and treatment of breast cancer. Recently, genome-wide 
expression studies have provided new fundamental knowledge about the effects of oestrogen inhibition on molecular profiles in breast cancer which have important clinical ramifications for the use of endocrine therapy. 


\section{REFERENCES}

[1] Jordan V.C and Furr B.J.A. An Introduction to the Regulation of Sex Steroids for the Treatment of Cancer. In V.C. Jordan and B.R.A. Furr (eds) Hormone Therapy in Breast and Prostate Cancer I pub Haman Press Totowa N.J., USA 2002 pp 185- 194.

[2] Miller W.R. Biological Rationale for Endocrine Therapy in Breast Cancer. Best Practice \& Research Clin Endocrinol \& Metab 18 (2003) pp 1-32.

[3] Jordan V.C. Tamoxifen for the Treatment of Breast Cancer. In V.C. Jordan and B.R.A. Furr (eds) Hormone Therapy in Breast and Prostate Cancer I Haman Press Totowa N.J., USA 2002 pp 1- 13.

[4] Miller W.R. Background and Development of Aromatase Inhibitors. In B J A Furr (ed) Aromatase Inhibitors Birkhauser Verlag Basel Boson Berlin 2006 pp 1 - 21.

[5] Bhatnagar AS, Miller WR. Pharmacology of inhibitors of estrogen biosynthesis. In: Born GV, (ed) Handbook of experimental pharmacology 135(2): estrogens, antiestrogens II: pharmacology and clinical application of estrogens and antiestrogens. M. Oettel, E. Schillinger (eds) Berlin Heidelberg: Springer-Verlag; 1999. pp 223-230.

[6] Miller, W. R., Bartlett, J., Brodie, A. M., Brueggemeier, R. W., di Salle, E., Lonning, P. E., Llombart, A., Maass, N., Maudelonde, T., Sasano, H. and Goss, P. E., Aromatase inhibitors: are there differences between steroidal and nonsteroidal aromatase inhibitors and do they matter?, Oncologist 13 (2008) pp 829-37.

[7] Reed, M. J., Aherne, G. W., Ghilchik, M. W., Patel, S. and Chakraborty, J., Concentrations of oestrone and 4-hydroxyandrostenedione in malignant and normal breast tissues, Int J Cancer 49 (1991) pp 562-5.

[8] Miller, W. R. and O'Neill, J., The importance of local synthesis of estrogen within the breast, Steroids 50 (1987) pp 537-48.

[9] James V.H.T., Reed M.J., Adams E.F., Ghilchik M.W., Lai L.C., Coldham N.G., Newton C.J., Purohit A., Owen A.M., Singh A, Islam S. Oestrogen uptake and metabolism in vivo. Proceedings of the Royal Society of Edinburgh, 95B (1989) pp185-193.

[10] Miller, W. R., Stuart, M., Sahmoud, T. and Dixon, J. M., Anastrozole ('Arimidex') blocks oestrogen synthesis both peripherally and within the breast in postmenopausal women with large operable breast cancer, Br J Cancer 87 (2002) pp 950-5.

[11] Miller, W. R., Aromatase inhibitors and breast cancer, Minerva Endocrinol 31 (2006) 27-46. 
[12] Miller, W. R., Larionov, A. A., Renshaw, L., Anderson, T. J., White, S., Murray, J., Murray, E., Hampton, G., Walker, J. R., Ho, S., Krause, A., Evans, D. B. and Dixon, J. M., Changes in breast cancer transcriptional profiles after treatment with the aromatase inhibitor, letrozole, Pharmacogenet Genomics 17 (2007) pp 813-26.

[13] Mackay, A., Urruticoechea, A., Dixon, J. M., Dexter, T., Fenwick, K., Ashworth, A., Drury, S., Larionov, A., Young, O., White, S., Miller, W. R., Evans, D. B. and Dowsett, M., Molecular response to aromatase inhibitor treatment in primary breast cancer, Breast Cancer Res 9 (2007) pp R37.

[14] Miller, W. R., Larionov, A., Renshaw, L., Anderson, T. J., Walker, J. R., Krause, A., Sing, T., Evans, D. B. and Dixon, J. M., Gene expression profiles differentiating between breast cancers clinically responsive or resistant to letrozole, J Clin Oncol 27 (2009) pp 1382-7.

[15] Miller, W. R., Larionov, A., Anderson, T. J., Walker, J. R., Krause, A., Evans, D. B. and Dixon, J. M., Predicting response and resistance to endocrine therapy: profiling patients on aromatase inhibitors, Cancer 112 (2008) pp 689-94.

[16] Ellis, M. J., Coop, A., Singh, B., Mauriac, L., Llombert-Cussac, A., Janicke, F., Miller, W. R., Evans, D. B., Dugan, M., Brady, C., Quebe-Fehling, E. and Borgs, M., Letrozole is more effective neoadjuvant endocrine therapy than tamoxifen for ErbB-1- and/or ErbB-2-positive, estrogen receptor-positive primary breast cancer: evidence from a phase III randomized trial, J Clin Oncol 19 (2001) pp 3808-16.

[17] Miller, W. R., Dixon, J. M., Macfarlane, L., Cameron, D. and Anderson, T. J., Pathological features of breast cancer response following neoadjuvant treatment with either letrozole or tamoxifen, Eur J Cancer 39 (2003) pp 462-8.

[18] Mello-Grand, M., Singh, V., Ghimenti, C., Scatolini, M., Regolo, L., Grosso, E., Zambelli, A., Da Prada, G. A., Villani, L., Fregoni, V., Baiardi, P., Marsoni, S., Miller, W. R., Costa, A. and Chiorino, G., Gene expression profiling and prediction of response to hormonal neoadjuvant treatment with anastrozole in surgically resectable breast cancer, Breast Cancer Res Treat 121 (2010) pp 399-411.

[19] Harvell, D. M., Spoelstra, N. S., Singh, M., McManaman, J. L., Finlayson, C., Phang, T., Trapp, S., Hunter, L., Dye, W. W., Borges, V. F., Elias, A., Horwitz, K. B. and Richer, J. K., Molecular signatures of neoadjuvant endocrine therapy for breast cancer: characteristics of response or intrinsic resistance, Breast Cancer Res Treat 112 (2008) pp475-88.

[20] Creighton, C. J., Li, X., Landis, M., Dixon, J. M., Neumeister, V. M., Sjolund, A., Rimm, D. L., Wong, H., Rodriguez, A., Herschkowitz, J. I., Fan, C., Zhang, X., He, X., Pavlick, A., Gutierrez, M. C., Renshaw, L., Larionov, A. A., Faratian, D., Hilsenbeck, S. G., Perou, C. M., Lewis, M. T., Rosen, J. M. and Chang, J. C., Residual breast cancers after conventional therapy display 
mesenchymal as well as tumor-initiating features, Proc Natl Acad Sci U S A 106 (2009) pp138205.

[21] Miller WR, Larionov AA, Ivens A, Anderson TJ, Evans DB, Dixon JM Sequential changes in gene expression profiles in breast cancers during treatment with the aromatase inhibitor, letrozole. Pharmacogenomics J (2010) in press.

[22] Itoh, T., Karlsberg, K., Kijima, I., Yuan, Y. C., Smith, D., Ye, J. and Chen, S., Letrozole-, anastrozole-, and tamoxifen-responsive genes in MCF-7aro cells: a microarray approach, Mol Cancer Res 3 (2005) pp 203-18.

[23] Frasor, J., Danes, J. M., Komm, B., Chang, K. C., Lyttle, C. R. and Katzenellenbogen, B. S., Profiling of estrogen up- and down-regulated gene expression in human breast cancer cells: insights into gene networks and pathways underlying estrogenic control of proliferation and cell phenotype, Endocrinology 144 (2003) pp 4562-74.

[24] Molloy, C. A., May, F. E. and Westley, B. R., Insulin receptor substrate-1 expression is regulated by estrogen in the MCF-7 human breast cancer cell line, J Biol Chem 275 (2000) pp 12565-71.

[25] Dressman, M. A., Walz, T. M., Lavedan, C., Barnes, L., Buchholtz, S., Kwon, I., Ellis, M. J. and Polymeropoulos, M. H., Genes that co-cluster with estrogen receptor alpha in microarray analysis of breast biopsies, Pharmacogenomics J 1 (2001) pp 135-41.

[26] Miller WR, Krause A, Larionov A, Evans DB, Anderson TJ, Dixon JM Genes discriminating between breast cancers responsive or resistant to the aromatase inhibitor, letrozole. Eur J Clin Med Oncol (2010) in press.

[27] Aitken, S. C. and Lippman, M. E., Effect of estrogens and antiestrogens on growthregulatory enzymes in human breast cancer cells in tissue culture, Cancer Res 45 (1985) pp 161120.

[28] Foster, J. S. and Wimalasena, J., Estrogen regulates activity of cyclin-dependent kinases and retinoblastoma protein phosphorylation in breast cancer cells, Mol Endocrinol 10 (1996) pp 48898.

[29] Moggs, J. G., Murphy, T. C., Lim, F. L., Moore, D. J., Stuckey, R., Antrobus, K., Kimber, I. and Orphanides, G., Anti-proliferative effect of estrogen in breast cancer cells that re-express ERalpha is mediated by aberrant regulation of cell cycle genes, J Mol Endocrinol 34 (2005) pp 535-51.

[30] Sutherland, R. L. and Musgrove, E. A., Cyclins and breast cancer, J Mammary Gland Biol Neoplasia 9 (2004) pp 95-104. 
[31] Ghosh, M. G., Thompson, D. A. and Weigel, R. J., PDZK1 and GREB1 are estrogenregulated genes expressed in hormone-responsive breast cancer, Cancer Res 60 (2000) pp 636775.

[32] Miller, W. R., White, S., Dixon, J. M., Murray, J., Renshaw, L. and Anderson, T. J., Proliferation, steroid receptors and clinical/pathological response in breast cancer treated with letrozole, Br J Cancer 94 (2006) pp 1051-6.

[33] McCready, J., Arendt, L. M., Rudnick, J. A. and Kuperwasser, C., The contribution of dynamic stromal remodeling during mammary development to breast carcinogenesis, Breast Cancer Res 12 (2010) 205.

[34] Finak, G., Bertos, N., Pepin, F., Sadekova, S., Souleimanova, M., Zhao, H., Chen, H., Omeroglu, G., Meterissian, S., Omeroglu, A., Hallett, M. and Park, M., Stromal gene expression predicts clinical outcome in breast cancer, Nat Med 14 (2008) 518-27.

[35] Miller, W. R., Clinical, pathological, proliferative and molecular responses associated with neoadjuvant aromatase inhibitor treatment in breast cancer, J Steroid Biochem Mol Biol 118 (2010) pp 273-6. 


\section{TABLES}

Table 1: Enriched GO terms for Biological Functions

\begin{tabular}{|c|c|c|c|}
\hline \multicolumn{4}{|c|}{ Down-regulated genes } \\
\hline \multicolumn{2}{|c|}{2 weeks } & \multicolumn{2}{|l|}{3 months } \\
\hline GO Term & $\mathrm{p}$ & GO Term & $\mathrm{p}$ \\
\hline M phase & $1.08 \mathrm{E}-38$ & cellular metabolic process & $1.52 \mathrm{E}-16$ \\
\hline cell cycle phase & $3.16 \mathrm{E}-37$ & generation of precursor metabolites and energy & $7.28 \mathrm{E}-14$ \\
\hline chromosome segregation & $1.34 \mathrm{E}-34$ & proteasomal protein catabolic process & 7.94E-14 \\
\hline mitotic cell cycle & $1.48 \mathrm{E}-34$ & proteasomal ubiquitin-dependent protein catabolic process & $7.94 \mathrm{E}-14$ \\
\hline nuclear division & $1.87 \mathrm{E}-33$ & mitotic cell cycle & $9.54 \mathrm{E}-14$ \\
\hline Mitosis & $1.87 \mathrm{E}-33$ & oxidative phosphorylation & 1.35E-12 \\
\hline M phase of mitotic cell cycle & $1.16 \mathrm{E}-32$ & mRNA metabolic process & $1.84 \mathrm{E}-12$ \\
\hline organelle fission & $3.79 \mathrm{E}-32$ & metabolic process & $3.45 \mathrm{E}-12$ \\
\hline cell cycle process & $1.65 \mathrm{E}-29$ & DNA metabolic process & 4.38E-12 \\
\hline cell cycle checkpoint & 5.17E-28 & M phase & 3.84E-11 \\
\hline cell cycle & $6.04 \mathrm{E}-27$ & RNA splicing & 7.12E-11 \\
\hline cell division & $1.24 \mathrm{E}-21$ & mRNA processing & $9.93 \mathrm{E}-11$ \\
\hline microtubule cytoskeleton organization & 7.64E-19 & RNA processing & $2.05 \mathrm{E}-10$ \\
\hline regulation of cell cycle & $1.08 \mathrm{E}-18$ & nucleobase biosynthetic process & $2.24 \mathrm{E}-10$ \\
\hline DNA replication & $2.48 \mathrm{E}-18$ & $\begin{array}{l}\text { anaphase-promoting complex-dependent proteasomal ubiquitin- } \\
\text { dependent protein catabolic process }\end{array}$ & $2.29 \mathrm{E}-10$ \\
\hline microtubule-based process & $1.09 \mathrm{E}-16$ & nucleotide biosynthetic process & $3.25 \mathrm{E}-10$ \\
\hline Chromosome & $9.76 \mathrm{E}-16$ & regulation of ubiquitin-protein ligase activity during mitotic cell cycle & $1.05 \mathrm{E}-09$ \\
\hline Spindle & $3.53 E-15$ & protein folding & $1.06 \mathrm{E}-09$ \\
\hline DNA conformation change & $5.41 \mathrm{E}-15$ & chromosome segregation & $1.40 \mathrm{E}-09$ \\
\hline regulation of mitotic cell cycle & $8.68 \mathrm{E}-15$ & primary metabolic process & $2.85 \mathrm{E}-09$ \\
\hline \multicolumn{4}{|c|}{ Up-regulated genes } \\
\hline \multicolumn{2}{|c|}{2 weeks } & \multicolumn{2}{|l|}{3 months } \\
\hline GO Term & $p$ & GO Term & $p$ \\
\hline blood vessel development & $1.16 \mathrm{E}-10$ & multicellular organismal development & $2.59 \mathrm{E}-16$ \\
\hline vasculature development & 2.66E-10 & cell adhesion & 8.70E-16 \\
\hline regulation of response to stimulus & $3.86 \mathrm{E}-10$ & biological adhesion & 8.70E-16 \\
\hline response to wounding & $6.29 \mathrm{E}-10$ & system development & $1.23 \mathrm{E}-15$ \\
\hline response to external stimulus & 3.47E-09 & organ development & $1.66 \mathrm{E}-15$ \\
\hline regulation of immune response & 4.35E-09 & anatomical structure development & $1.05 \mathrm{E}-14$ \\
\hline organ development & $1.07 \mathrm{E}-07$ & skin development & $4.58 \mathrm{E}-14$ \\
\hline system development & $4.42 \mathrm{E}-07$ & developmental process & $1.39 \mathrm{E}-13$ \\
\hline multicellular organismal development & $1.66 \mathrm{E}-06$ & blood vessel development & $3.63 E-13$ \\
\hline \multirow{6}{*}{ regulation of immune system process } & 3.64E-06 & vasculature development & 1.39E-12 \\
\hline & & negative regulation of biological process & 3.34E-12 \\
\hline & & collagen fibril organization & $4.88 \mathrm{E}-11$ \\
\hline & & extracellular matrix organization & $1.67 \mathrm{E}-10$ \\
\hline & & biological regulation & $1.91 \mathrm{E}-10$ \\
\hline & & multicellular organismal process & 3.99E-10 \\
\hline
\end{tabular}


Table 2: Enriched GO terms for Cellular Compartment

\begin{tabular}{|c|c|c|c|}
\hline \multicolumn{4}{|c|}{ Down-regulated genes } \\
\hline \multicolumn{2}{|l|}{2 weeks } & \multicolumn{2}{|l|}{3 months } \\
\hline GO Term & pvalue & GO Term & pvalue \\
\hline chromosome & $9.76 \mathrm{E}-16$ & mitochondrion & $9.26 \mathrm{E}-39$ \\
\hline spindle & $3.53 E-15$ & organelle inner membrane & $1.04 \mathrm{E}-36$ \\
\hline chromosomal part & $1.38 \mathrm{E}-14$ & mitochondrial inner membrane & 2.44E-34 \\
\hline microtubule cytoskeleton & 9.39E-09 & mitochondrial part & $5.25 E-33$ \\
\hline non-membrane-bounded organelle & $1.42 \mathrm{E}-07$ & intracellular organelle part & 2.70E-27 \\
\hline intracellular non-membrane-bounded organelle & $1.42 \mathrm{E}-07$ & organelle part & $6.72 E-27$ \\
\hline nuclear part & $6.58 \mathrm{E}-07$ & organelle envelope & $2.76 \mathrm{E}-25$ \\
\hline nuclear lumen & 4.05E-05 & envelope & 4.61E-25 \\
\hline nucleus & 5.29E-05 & intracellular part & $7.28 \mathrm{E}-25$ \\
\hline nucleoplasm & $6.75 E-05$ & macromolecular complex & 1.65E-24 \\
\hline \multicolumn{4}{|c|}{ Up-regulated genes } \\
\hline \multicolumn{2}{|l|}{ 2weeks } & \multicolumn{2}{|l|}{3 months } \\
\hline GO Term & pvalue & GO Term & pvalue \\
\hline extracellular matrix & 4.76E-41 & proteinaceous extracellular matrix & 8.46E-34 \\
\hline proteinaceous extracellular matrix & $5.81 E-41$ & extracellular matrix & 3.77E-32 \\
\hline extracellular region part & $9.16 \mathrm{E}-38$ & extracellular region part & $4.80 \mathrm{E}-29$ \\
\hline extracellular matrix part & $7.51 \mathrm{E}-30$ & extracellular matrix part & 7.97E-25 \\
\hline extracellular region & 3.57E-24 & extracellular region & 1.37E-23 \\
\hline extracellular space & 2.03E-18 & fibrillar collagen & $2.92 \mathrm{E}-17$ \\
\hline vacuole & $1.60 \mathrm{E}-14$ & collagen & $3.81 \mathrm{E}-15$ \\
\hline lytic vacuole & $8.60 \mathrm{E}-14$ & basement membrane & $5.84 \mathrm{E}-09$ \\
\hline lysosome & $8.60 \mathrm{E}-14$ & extracellular space & 3.90E-06 \\
\hline
\end{tabular}

Table Legends: Bold text indicates that the term appears in both 14 day and 3 month lists 
Figure 1: Most enriched GO terms for genes changed at different timepoints of treatment with Letrozole
A: Most down-regulated GO terms
chromosome mitochondrion

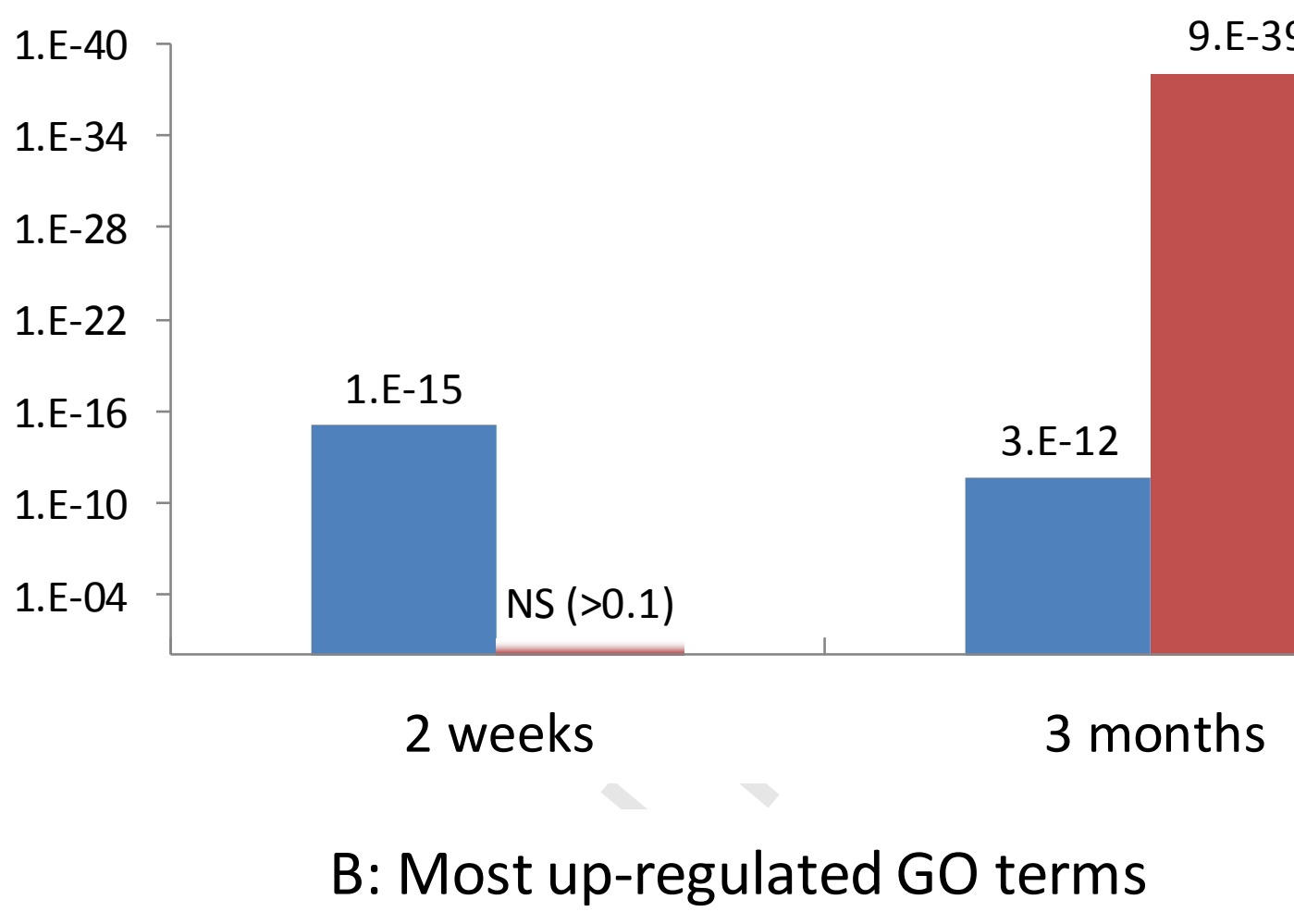

blood vessel development cell adhesion

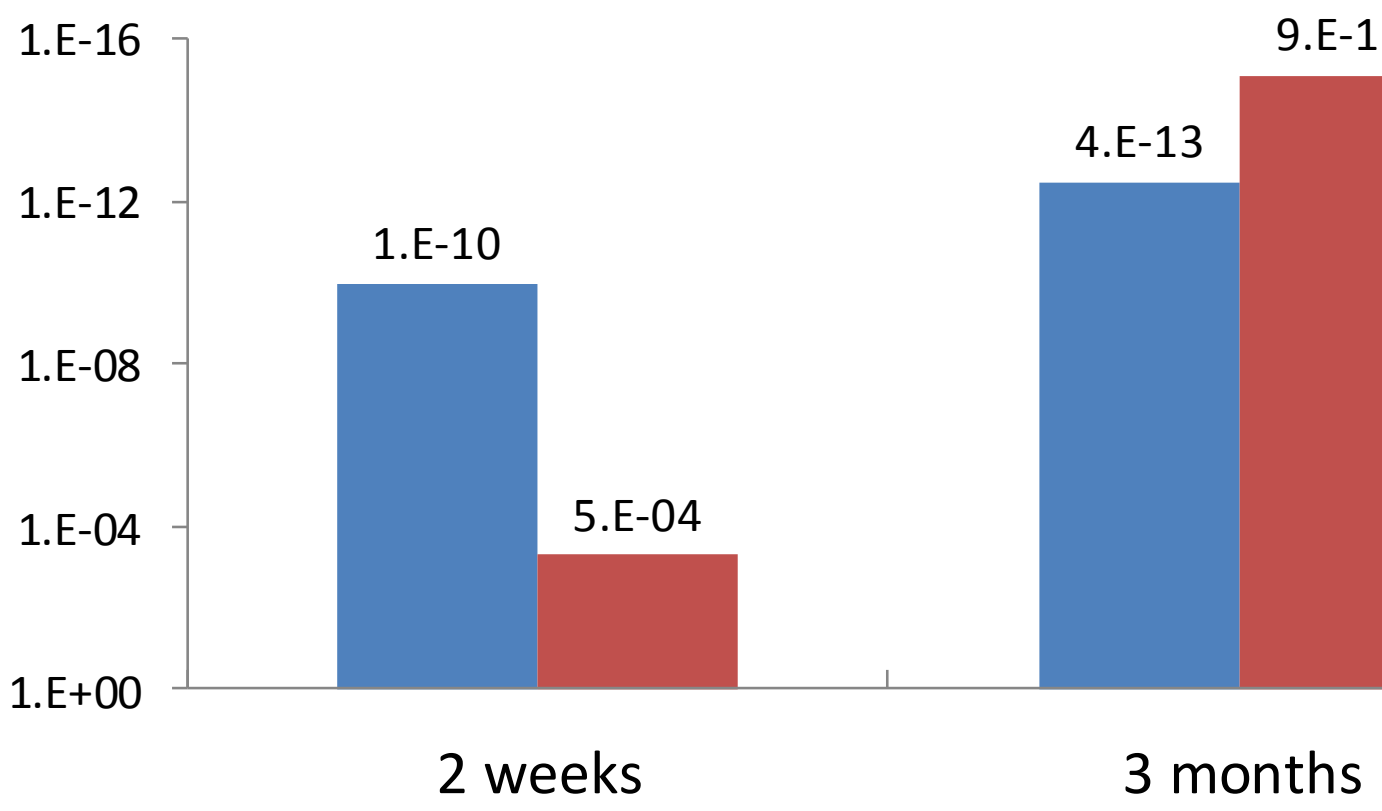

Vertical axes show $\mathrm{p}$-value for GO terms enrichment $(\log 10)$ 


\section{Figure2: Patterns of genes expression changes}

\section{A: Group of genes displaying quick, gradual and delayed response to oestrogen deprivation}

Down-regulated genes

$-70-602-143$

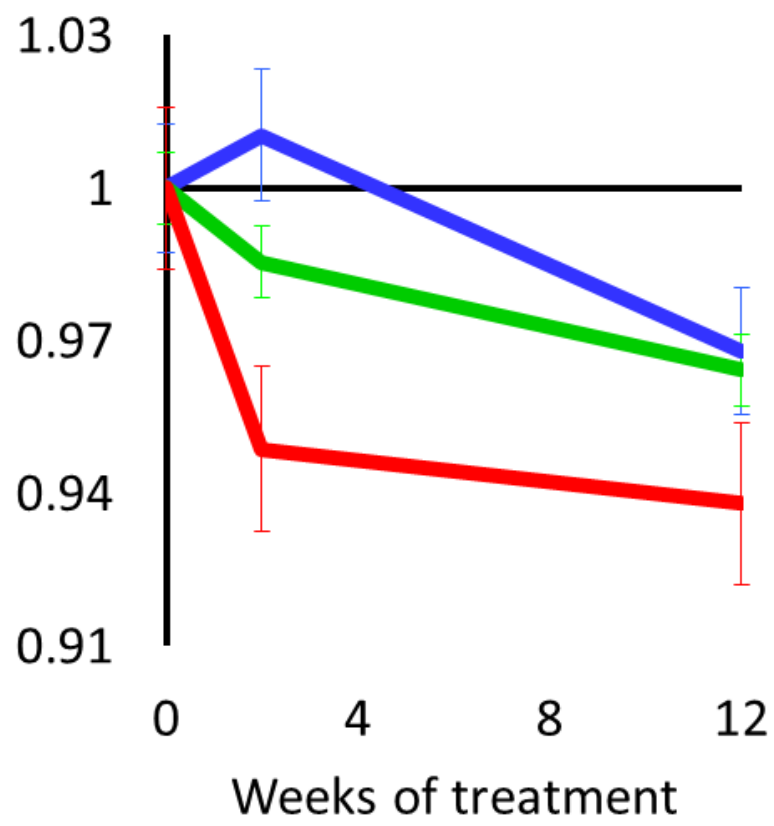

Up-regulated genes
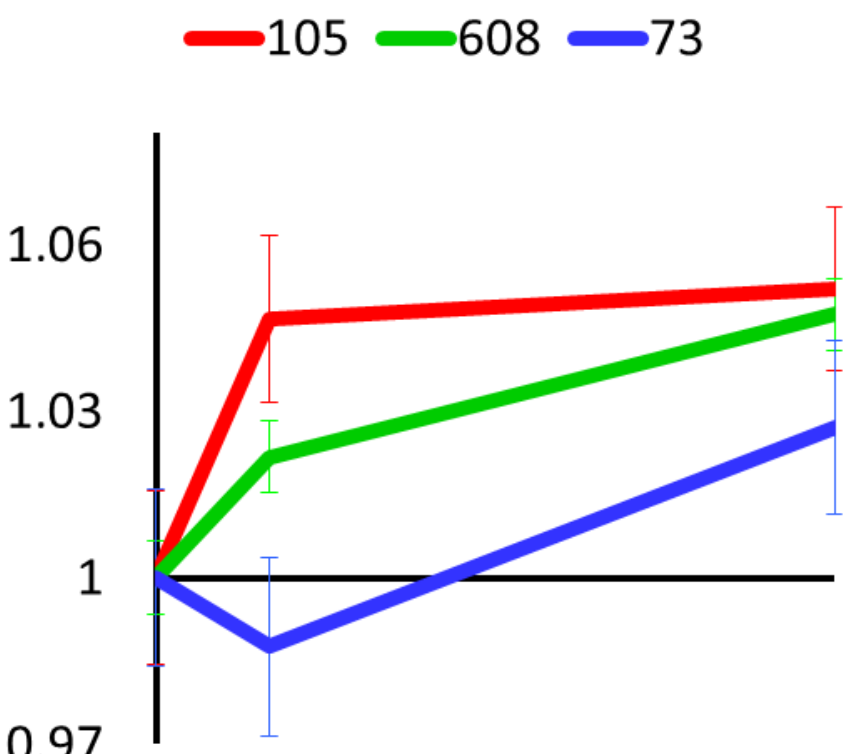

0

4
12

Legend: Y-axes show mRNA expression, Mean +/- CV of mean, log2, relative to baseline. Red - quick changes, green -steady changes, blue - delayed changes, figures show number of genes in each group.

B: Examples of changes in individual genes

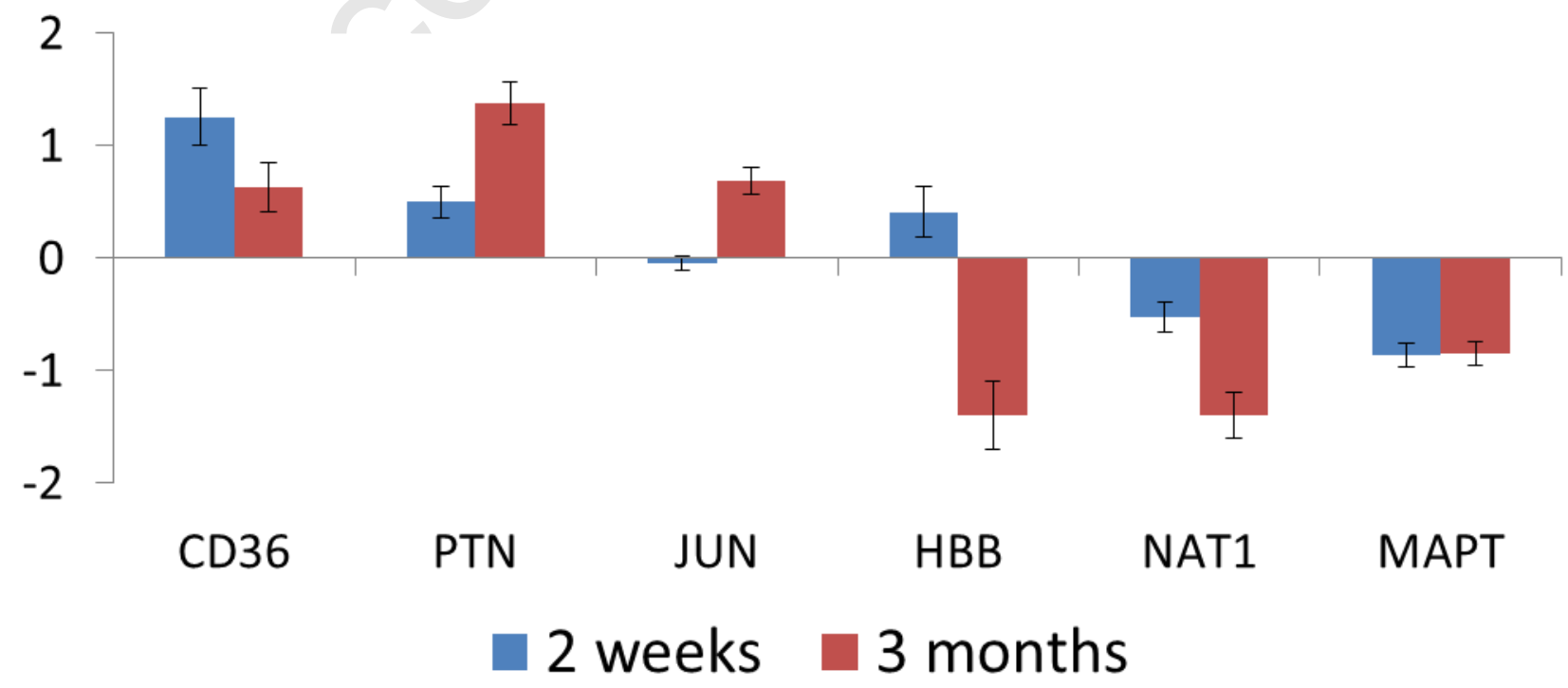




\section{Figure 3: Change in selected genes during treatment with letrozole}

A: ESR1

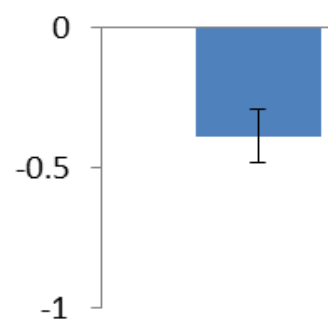

$-1$

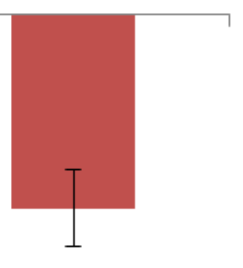

ESR1_2

C: Classical oestrogen-stimulated genes

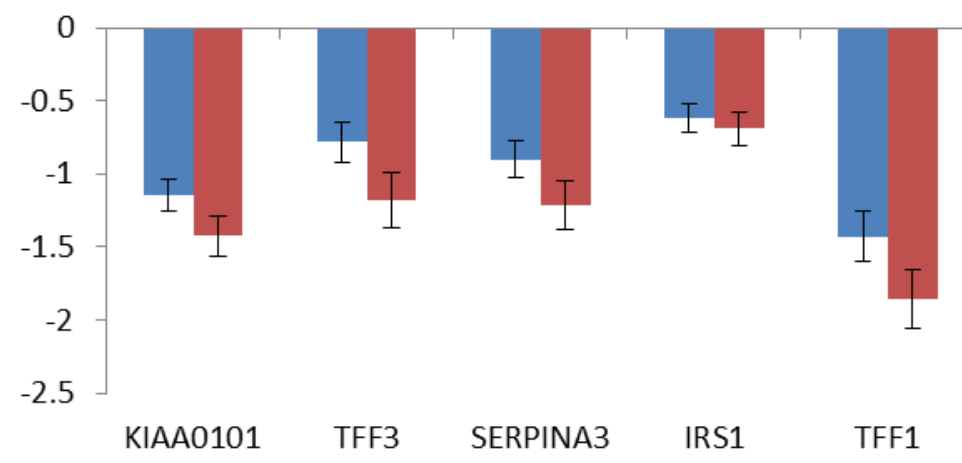

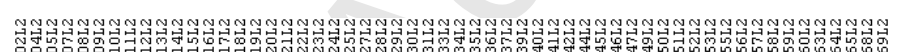

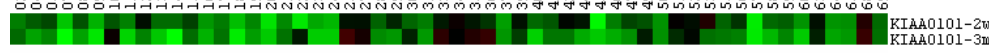

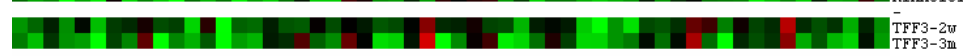

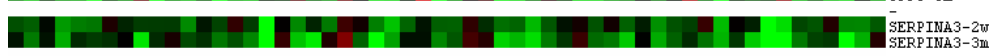

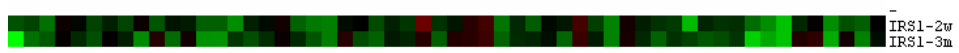

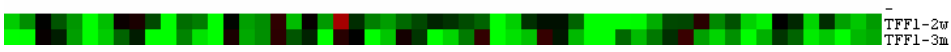

B: TP53

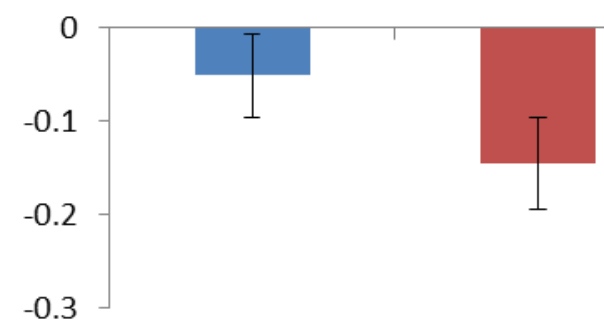

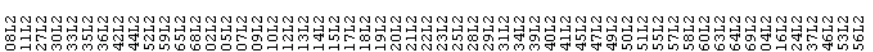

D: Proliferation associated genes
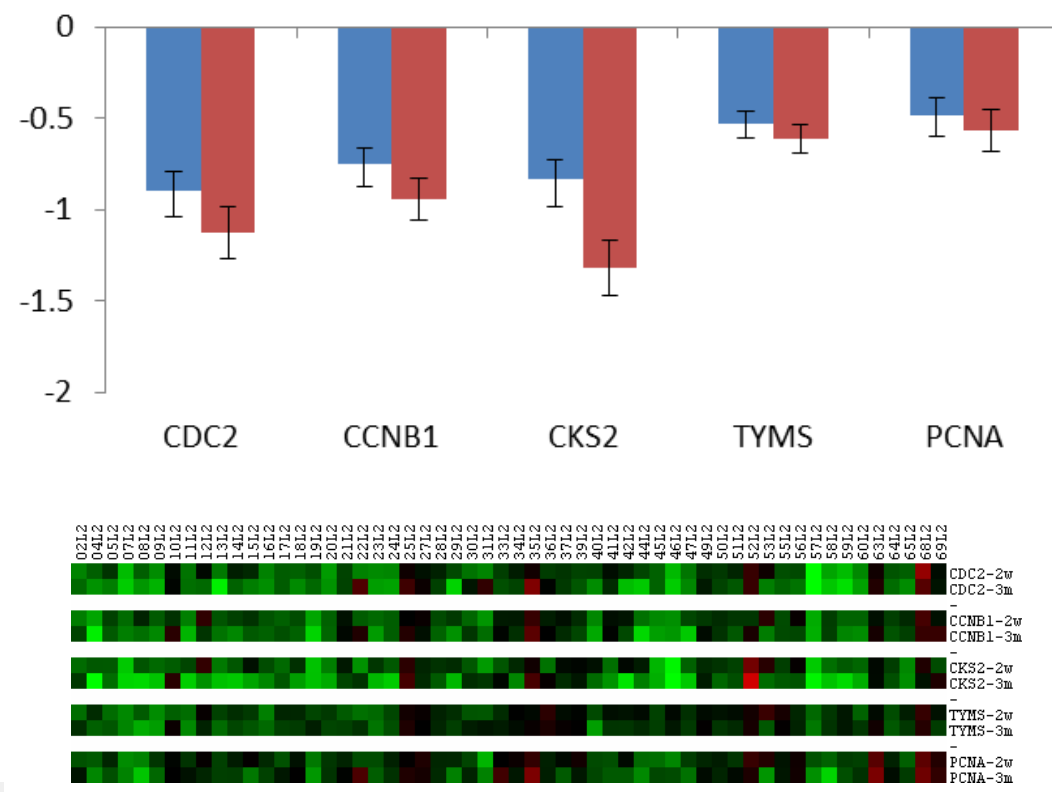

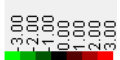

Legend: $Y$ axes show change in mRNA expression, log2; Bars show mean change +/- SEM; blue bars show change at 2 weeks and red bars show change at 3 months. On heatmaps: two lines are shown for each gene. Upper line shows change at 2 weeks, lower line shows change at 3 months. 


\section{Figure 4: Early changes in selected ribosomal proteins are associated with neo-adjuvant response to Letrozole}

A: Average changes for groups of genes

D14

0.4
0.3
0.2
0.1
0
-0.1
-0.2
$3 M$

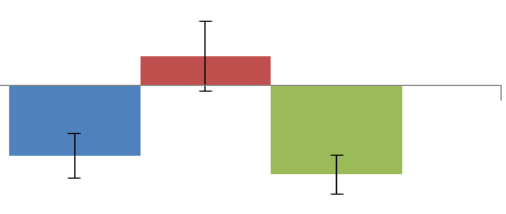

Responders

\section{B: Changes in individual tumours}

\section{2 weeks}

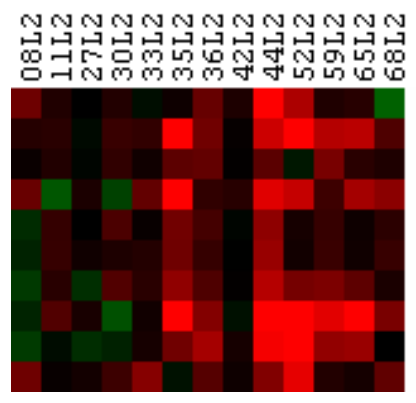

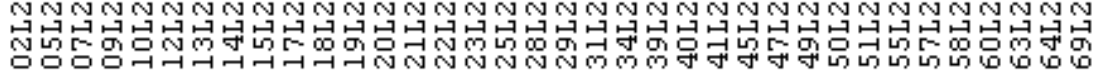

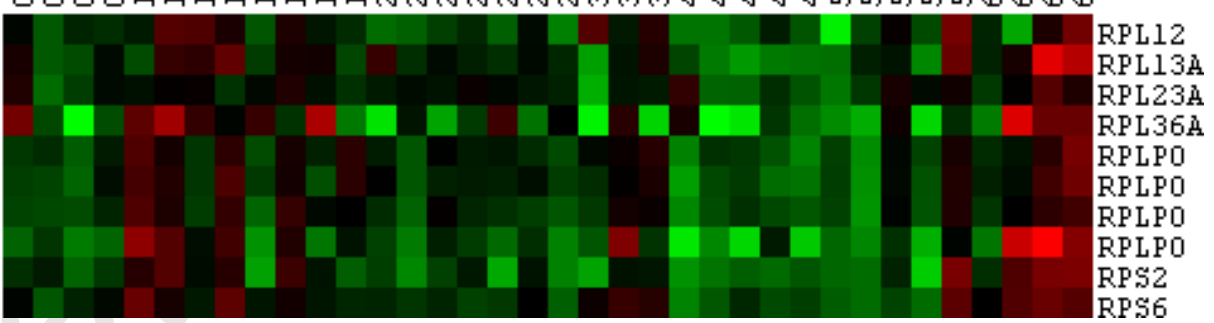

3months

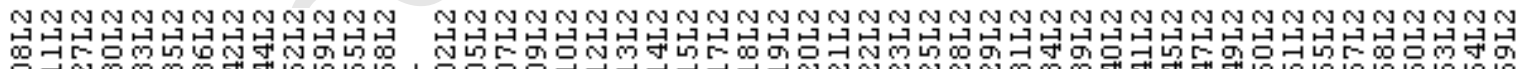

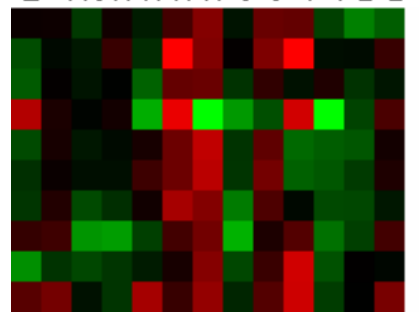

Non-Responders

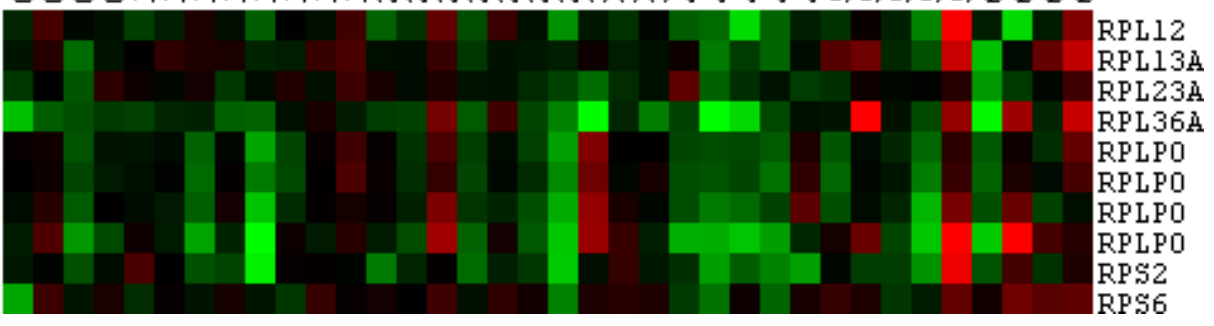

Respondrs 
Figure 5: Changes in genes associated with stromal response and energy metabolism

A: Stromal response associated genes

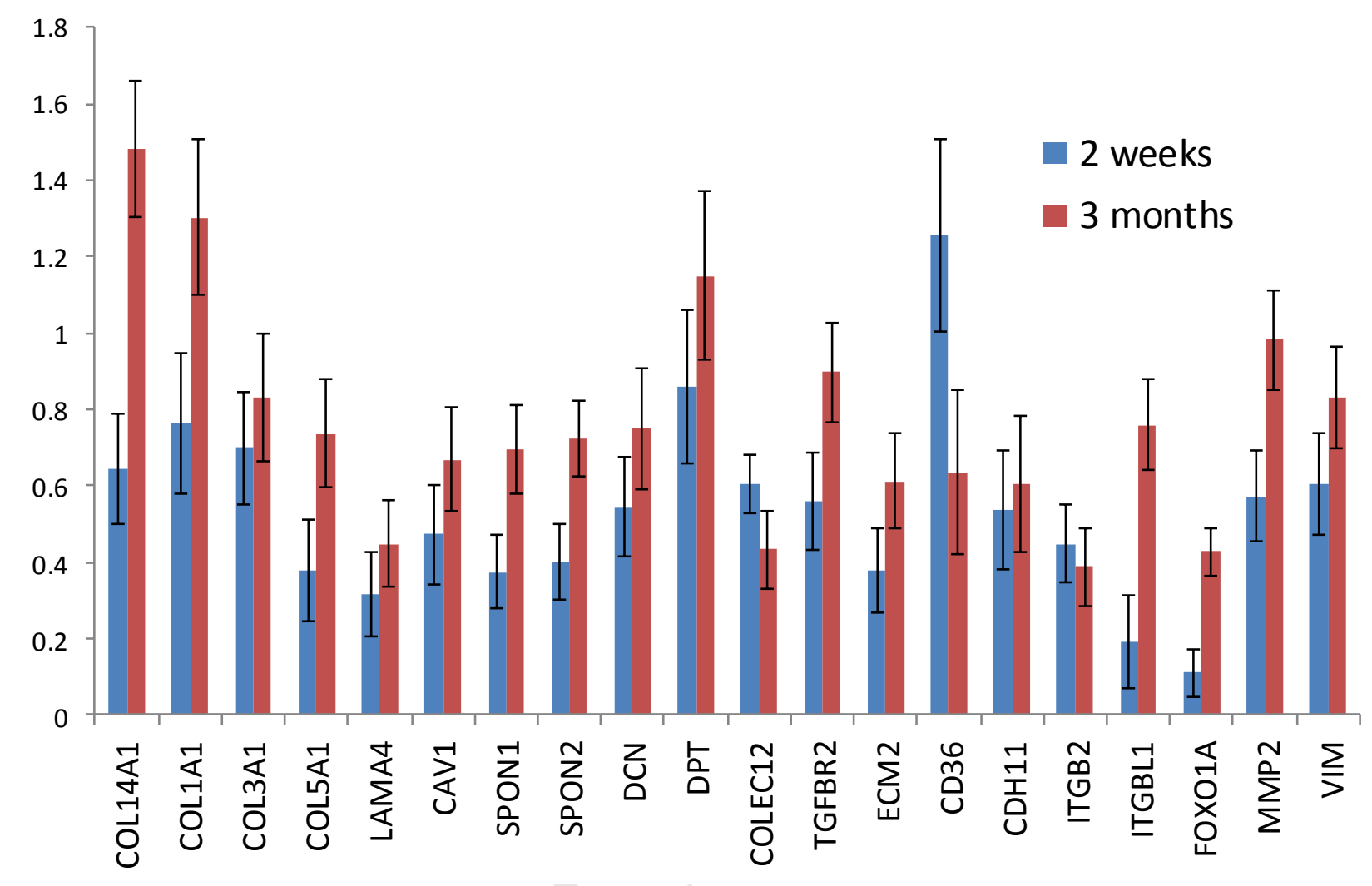

2 weeks

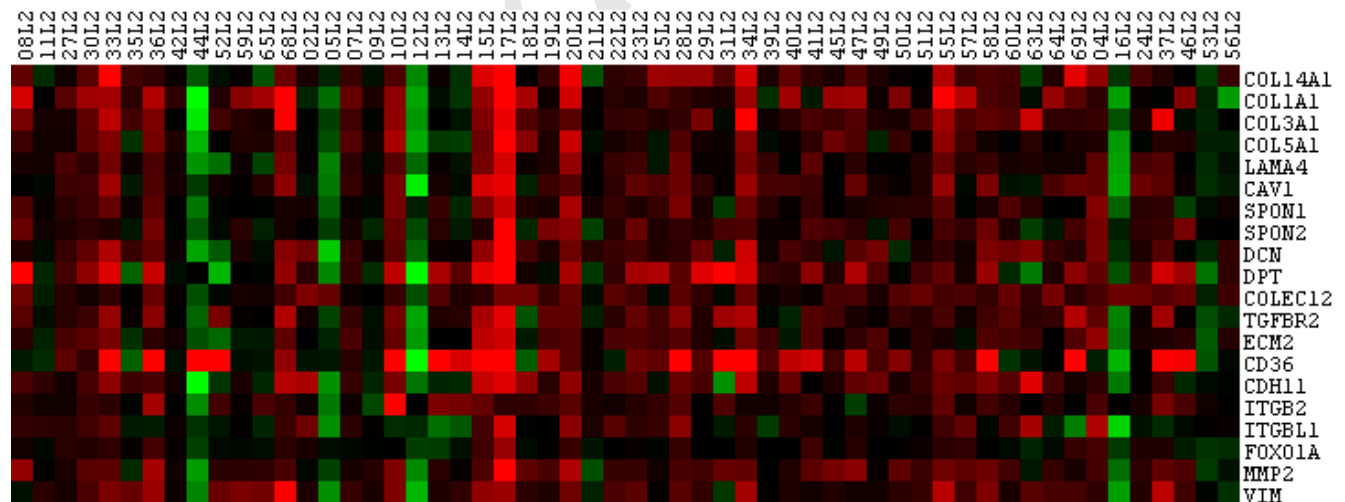

3 months

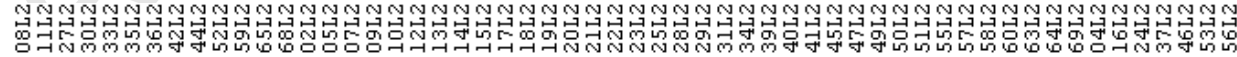

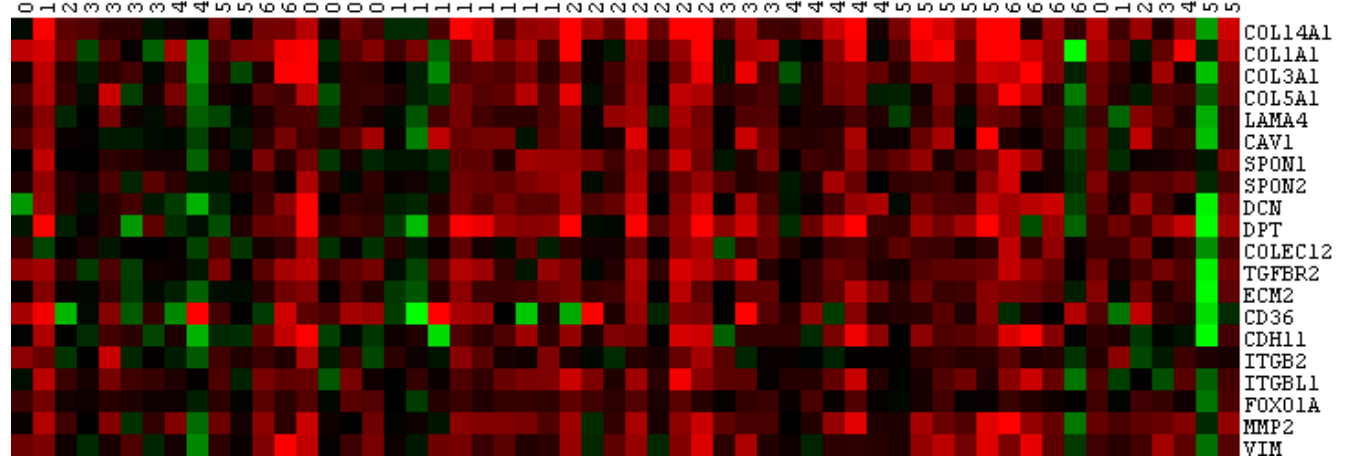

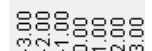




\section{B: Oxidative phosphorylation associated genes}
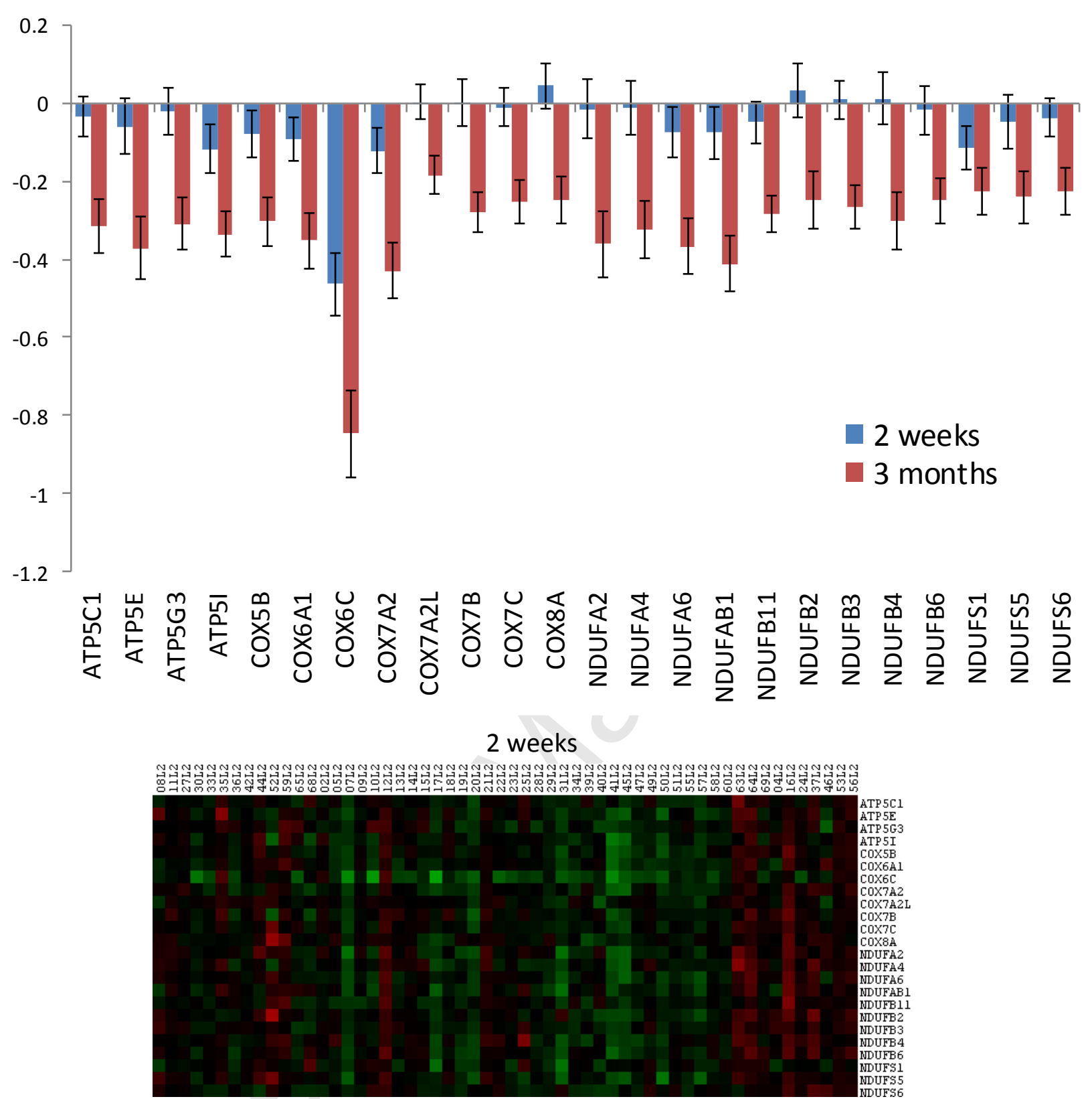

3 months

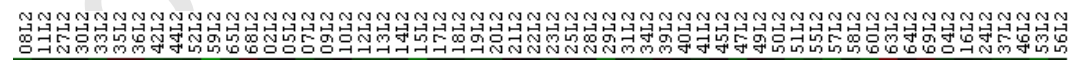

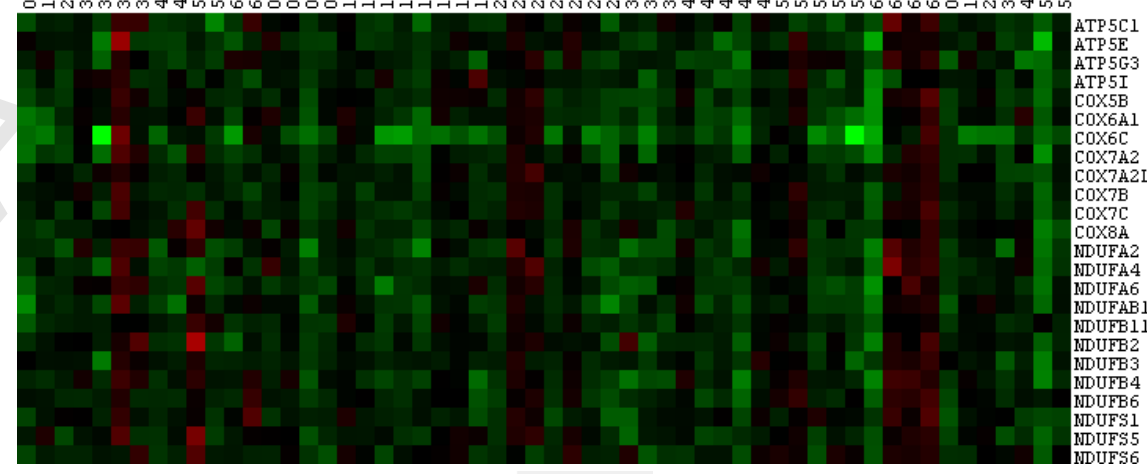

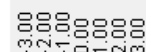

Legend: $\mathrm{Y}$ axes on bar diagrams show change in mRNA expression, log2; Bars show mean change +/- SEM, 